\title{
MASS BALANCE OF THE GREENLAND ICE SHEET AT DYE 3
}

\author{
By Niels ReEH* and Niels S. Gundestrup
}

(Department of Glaciology, Geophysical Institute, Haraldsgade 6, DK-2200 Copenhagen N, Denmark)

ABstract. The mass balance of the Greenland ice sheet at Dye 3 is estimated on the basis of observations of ice thickness, accumulation rate, surface velocities, and surface strain-rates. The calculations indicate a rate of increase of surface elevation of $3 \mathrm{~cm} /$ year, with $95 \%$ confidence limits of $-3 \mathrm{~cm} /$ year and $+9 \mathrm{~cm} /$ year. Previous estimates of the mass balance of the Greenland ice sheet by the same method reported large imbalances; these are most probably due to lack of precise data and the use of quantities measured at the surface as representative of depth-averaged quantities. The most reliable observations indicate that the interior regions of the Greenland ice sheet are at present thickening at a rate of a few centimetres per year; a contributing cause for this may be the slow thinning of a bottom layer of relatively sof $t$ Wisconsin ice.

RÉsumÉ. Bilan de masse de l'Indlandsis Groenlandais à Dye 3. Le bilan de masse est estimé à partir des mesures d'épaisseur, taux d'accumulation, vitesses et vitesses de déformation superficielles. Le calcul donne un épaississement de $3 \mathrm{~cm} a^{-1}$ avec un intervalle de confiance, au seuil de $95 \%$, allant de $-3 \mathrm{~cm} \mathrm{an}^{-1}$ à +9 $\mathrm{cm} \mathrm{an}^{-1}$. Les estimations antérieures du bilan de l'Indlandsis obtenues par la même méthode sont examinées. On en déduit que les valeurs de bilan très éloignées de l'équilibre sont certainement dues au manque de données précises et/ou à l'utilisation de données superficielles comme valeurs moyennes sur une

\section{INTRODUCTION}

In connection with the deep drilling at Dye 3 , south Greenland (lat. $65^{\circ} 11^{\prime} \mathrm{N}$., long. $43^{\circ} 49^{\prime} \mathrm{W}$.), a glaciological programme was carried out up-stream of the drill site The programme included observations of surface topography, ice-thickness profiles, surface velocities, surface strain-rates, and accumulation-rate distribution (Whillans and others, 1984; Overgaard and Gundestrup, in press; Reeh and others, in press).

Combining the results of these investigations with velocity-depth data obtained from down-bore-hole inclinometry measurements (Gundestrup and Hansen, 1984), the local mass balance of the ice sheet at Dye 3 can be estimated.

\section{EQUATION OF CONTINUITY}

Introducing a horizontal $x-y$ coordinate system, the local continuity equation for the ice sheet may be expressed as follows (Mellor, 1968):

$\frac{\partial H}{\partial t}=a-H\left[\frac{\partial u_{\mathrm{m}}}{\partial x}+\frac{\partial v_{\mathrm{m}}}{\partial y}\right]-u_{\mathrm{m}} \frac{\partial H}{\partial x}-v_{\mathrm{m}} \frac{\partial H}{\partial y}$

where $H$ is the ice thickness (in metres of ice equivalent), $t$ the time, $a$ the accumulation rate (in

* Present address: The Geological Survey of Greenland, Øster Voldgade 10, DK-1350 Copenhagen K, Denmark. verticale. On conclut que les observations les plus sures montrent que les régions centrales du Groenland s'épaississent actuellement de quelques centimètres par an et qu'une des causes en est probablement l'amincissement lent d'une couche basale de glace plus facilement déf ormable datant du Wisconsin.

Zusammenfassung. Massenbilanz des grönländischen Inlandeises bei Dye 3. Die Massenbilanz des grönländischen Inlandeises bei Dye 3 wird auf der Grundlage von Beobachtungen der Eisdicke, der Akkumualtionsrate sowie der Geschwindigkeiten und Spannungsraten an der Oberfläche abgeschätzt. Die Berechnungen ergeben eine Zuwachsrate der Eisdicke/Oberflächenhöhe von $3 \mathrm{~cm}$ pro Jahr mit einem $95 \%-K o n f i d e n z b e r e i c h$ von $-3 \mathrm{~cm}$ und $+9 \mathrm{~cm}$ pro Jahr. Frühere Abschätzungen der Bilanz des grönländischen Inlandeises mit derselben Methode werden überprüft, was zu dem Schluss führt, dass die festgestellten weitgehenden Unausgeglichenheiten meist auf dem Mangel an genauen Daten und/oder auf der Extrapolation von Oberflächenmessungen auf die gesamte zugehörige Eissäule beruhen. Es lässt sich sagen, dass die zuverlässigsten Beobachtungen derzeit auf eine Dickenzunahme der zentralen Region des grönlöndischen Inlandeises um wenige $\mathrm{cm}$ pro $\mathrm{Jahr}$ hindeuten und dass eine Teilursache für diese Zunahme vermutlich die langsam fortschreitende Ausdünnung einer Grundschicht relativ weichen Eises aus der Wisconsin-Vereisung ist.

metres of ice equivalent per year), and $u_{\mathrm{m}}$ and $v_{\mathrm{m}}$ are horizontal ice-flow velocities in the $x$ - and $y$-directions respectively, averaged over the ice thickness.

It is assumed that the depth-density profile is constant in time and space, and that the ice is frozen to the bed (the basal temperature at Dye 3 equals $-13.2^{\circ} \mathrm{C}$ according to Gundestrup and Hansen (1984)), so that there is no mass loss or gain at the bottom of the ice sheet. If we further assume that the $x$-axis is in the direction of flow, Equation (1) can be rewritten in terms of the surface velocity and surface strain-rates:

$\frac{\partial H}{\partial t}=a-\frac{1}{f}\left[H\left(\frac{\partial u_{\mathrm{S}}}{\partial x}+\frac{\partial v_{\mathrm{S}}}{\partial y}\right]+u_{\mathrm{S}} \frac{\partial H}{\partial x}\right]$

where the subscript $s$ indicates a value at the surface, and $f=u_{\mathrm{s}} / u_{\mathrm{m}}$ is a shape factor of the horizontal velocity profile, which is assumed not to vary along the flow line.

\section{THE DATA}

The coordinate system applied is the one used by Whillans and others (1984) with the $x$-axis coinciding with the ice-flow direction at the drill site. At this site, the following values of ice thickness and accumulation rate have been found: $H=2013 \mathrm{~m}$ of ice equivalent (Gundestrup and Hansen, 1984), $a=0.55 \mathrm{~m}$ of ice equivalent/year (Reeh and others, in press). The shape factor $f$ can be calculated by means of the velocity profile given by Gundestrup and Hansen (1984). The 
profile was determined by subtracting hole positions obtained by integrating the hole inclinations measured in 1981 and 1983 respectively, ignoring vertical strain.

The 1981 inclinations were measured with the inclinometers in the drill (Gundestrup and Hansen, 1984), and have an uncertainty of about $0.5^{\circ}$ at $6^{\circ}$ inclination, which can probably explain the difference between the bore-hole- and geoceiver-determined surface velocities of 13.5 and $12.5 \mathrm{~m} /$ year (see below), respectively. The difference, however, introduces an uncertainty in the calculation of the shape factor $f$, the value of which ranges between 1.13 and 1.10 depending on which surface velocity is used.

\section{Surface velocity at Dye 3}

The position of station $1,450 \mathrm{~m}$ from the Dye 3 deep drill site at direction $294^{\circ}$ true, was measured by Mock in 1972-73 and 1975 (Mock, 1976). Based on these positions, Mock estimated the surface velocity to be 1.8-12.7 m/year, direction $056^{\circ}$ to $061^{\circ}$ true. Since the 1972 position was obtained with a few satellite passes only, and the 1973 and 1975 positions were obtained at a different site and referenced to station 1 by survey, it is difficult to estimate the error.

In 1980, 1981, and 1983 the measurements were repeated by University of Copenhagen (UCPH) (Overgaard and Gundestrup, in press), and in 1980 and 1981 the station was part of the strain net established by Whillans and others (1984), who estimated the velocity to be $13.4 \mathrm{~m} /$ year in a direction $061^{\circ}$ true.

Table I shows positions (referenced to the WGS-72 ellipsoid; $a=6378.135, f=1 / 298.26$ ) of station 1 obtained by processing the Mock and UCPH measurements using precise satellite ephemeris.

\section{TABLE I. POSITIONS OF STATION 1}

$\begin{array}{lccc}\text { Year } & \begin{array}{c}\text { Latitude } \\ { }^{\circ} \mathrm{N}\end{array} & \begin{array}{c}\text { Longitude } \\ { }^{\mathrm{E}}\end{array} & \begin{array}{c}\text { Elevation } \\ \mathrm{m}\end{array} \\ 72.586 & 65.187391 & 316.169520 & 2526.76 \\ 80.626 & 65.187814 & 316.171377 & 2526.45 \\ 81.548 & 65.187878 & 316.171618 & 2529.68 \\ 83.422 & 65.187977 & 316.172051 & 2529.36\end{array}$

A linear fit to these data gives the velocity

$$
u_{\mathrm{S}}=12.5 \pm 0.1 \mathrm{~m} / \text { year, } 061.2^{\circ} \pm 0.5^{\circ} \text {. }
$$

The uncertainties are calculated on the assumption that all errors are random and therefore are formal errors. The 1972 position has a relatively high weight in this velocity calculation due to the long time interval to the next position determination. As the error in 1972 is uncertain and the definition of the satellite system was changed in June 1977, the 1972 position may be biased. If this position is omitted, the velocity is calculated to be

$$
u_{\mathrm{S}}=12.9 \pm 0.25 \mathrm{~m} / \text { year }, 060.4^{\circ} \pm 1.0^{\circ} \text {. }
$$

Surface strain may influence the calculation. The local longitudinal strain-rate is $0.63 \times 10^{-3}$ year $^{-1}$ (see below). With a movement of the station of $138 \mathrm{~m}$ between 1972 and 1983, this corresponds to an increase of surface velocity of only $0.09 \mathrm{~m} / \mathrm{year}$, and consequently cannot explain the difference of $0.4 \mathrm{~m} / \mathrm{year}$ between the two estimates.

In summary, $12.5 \mathrm{~m} /$ year is considered the best estimate, although the error of $0.1 \mathrm{~m} / \mathrm{year}$ is too small due to non-random sources of error.

\section{Surface strain-rates and ice-thickness gradient}

As to the strain-rates $\partial u_{\mathrm{S}} / \partial x$ and $\partial v_{\mathrm{S}} / \partial y$ and the thickness gradient $\partial H / \partial x$, two choices are possible: either apply strictly local values (averaged over distances of the order of $4 \mathrm{~km}$ ) or regional values averaged over distances of the order of $20 \mathrm{~km}$. Due to the rough basal topography up-stream of the drill site (Overgaard and Gundestrup, in press), local and regional thickness gradients and surface strain-rates show large differences, as illustrated in Table II. Results have been obtained from data presented in Overgaard and Gundestrup (in press) and Whillans and others (1984).

TABLE II. LOCAL AND REGIONAL VALUES OF SURFACE STRAIN-RATES AND ICE-THICKNESS GRADIENT AT DYE 3

$$
\begin{array}{cc}
\partial u_{\mathrm{s}} / \partial x & \partial v_{\mathrm{S}} / \partial y \\
\mathrm{a}^{-1} & \mathrm{a}^{-1}
\end{array}
$$$$
\text { Local } \quad 6.3 \times 10^{-4} \quad-0.9 \times 10^{-4} \quad-0.042 \pm 0.005
$$

Regional

values $\quad 2.8 \times 10^{-4}-0.3 \times 10^{-4} \quad 0.006 \pm 0.002$

\section{RESULTS}

There are arguments for applying local as well as regional values in Equation (2). The values applied for accumulation rate, ice thickness, surface velocity, and shape factor $f$ are local, thus favouring application of local values also for the remaining quantities in Equation (2). However, due to the velocity perturbations caused by the rough basal topography, the short-distance gradient of the shape factor may not be negligible, as assumed by Equation (2). The long-distance gradient of on the other hand is more likely to be negligible, suggesting use of regional average values. Thus, since there is no clear preference for applying local or regional values, calculations have been performed with both sets. The results are

$\partial H / \partial t=0.05 \mathrm{~m}$ of ice/year (local), and

$\partial H / \partial t=0.03 \mathrm{~m}$ of ice/year (regional).

Using the following estimates for the standard deviations: $s\left(u_{\mathrm{s}}\right)=0.1 \mathrm{~m} /$ year, $s(H)=10 \mathrm{~m}, s(f)=0.015$ $s(a)=0.015 \mathrm{~m} /$ year, $s\left(\partial u_{\mathrm{S}} / \partial x\right)=s\left(\partial v_{\mathrm{S}} / \partial y\right)=10^{-5}$ year $^{-1}$ (Whillans and others, 1984), and applying values of $s(\partial H / \partial x)$ as indicated in Table II, $s(\partial H / \partial t)=0.06 \mathrm{~m}$ of ice/year and $0.03 \mathrm{~m}$ of ice/year for the "local" and "regional" estimates, respectively.

Within the standard errors the two estimates therefore agree, and with $95 \%$ confidence, the present ice-thickness change at Dye 3 ranges between a thinning rate of $3 \mathrm{~cm} /$ year and a thickening rate of $9 \mathrm{~cm} /$ year. The largest contribution to $s(\partial H / \partial t)$ comes from the uncertainty of the thickness gradient. Therefore, increasing $s\left(u_{\mathrm{s}}\right)$ to e.g. $0.25 \mathrm{~m} /$ year (as suggested by the calculation omitting the 1972 position above) will not change the confidence limits significantly.

Since the value of the accumulation rate used in the calculations is an average over about the last hundred years, the suggested small imbalance of the ice sheet does not reflect a short-term accumulation-rate anomaly, but rather a long-term trend persistent over at least the last several decades.

\section{DISCUSSION AND CONCLUSIONS}

The method used in this study to estimate the mass balance of the Dye 3 area has been applied previously to several locations on the Greenland ice sheet (Shumskiy, 1965; Mellor, 1968; Mock, 1976). All previous estimates indicate large imbalances (up to more than 1 $\mathrm{m} /$ year), in some cases positive, in others negative. For example, Mellor (1968) estimated that the Dye 3 area has a positive balance of $1 \mathrm{~m} /$ year. However, this large value is based on application of unrealistically large values of the surface velocity ( $50 \mathrm{~m} /$ year) and transverse strain-rate $\left(-5.0 \times 10^{-4}\right.$ year $\left.^{-1}\right)$.

Generally, the previous mass-balance estimates suffer from a lack of precise data, and neglect of the 
differences between surface and average values. Mock (1976), for example, estimated the mass balance of the ice sheet at Crête (lat. $71^{\circ} 07^{\prime} \mathrm{N}$., long. $37^{\circ} 19^{\prime} \mathrm{W}$.) to be $\partial H / \partial t=-0.25 \mathrm{~m} /$ year. Using Equation (2) with $a=0.29$ $\mathrm{m}$ of ice equivalent per year, $H=3150 \mathrm{~m}, \partial u_{\mathrm{s}} / \partial x+$ $\partial v_{\mathrm{S}} / \partial y=1.24 \times 10^{-4} \mathrm{year}^{-1}$ (Reeh and others, 1978), $u_{\mathrm{S}}$ $=0$ (Crête is on the ice divide), and $f=1.13$ (the value at Dye 3), we obtain

$$
\begin{aligned}
\frac{\partial H}{\partial t} & =0.29-\frac{1}{1.13} 3150 \times 1.24 \times 10^{-4} \\
& =-0.06 \mathrm{~m} / \text { year }
\end{aligned}
$$

i.e. a much smaller negative balance than estimated by Mock. Furthermore, the $f$-value at Crête is likely to be considerably larger than at Dye 3 due to a relatively thicker layer of soft Wisconsin ice (see discussion below) and also due to the ice-divide effect discussed by Reeh and others (1978) and Raymond (1984). Changing $f$ to 1.6 for example, which is not an unrealistic value for Crête, will change $\partial H / \partial t$ to a positive value of 0.05 $\mathrm{m} /$ year, which is in accordance with the observations of Seckel (1977) for the period 1959-68, who determined the surface-elevation change in a profile across the ice sheet at lat. $70-72^{\circ} \mathrm{N}$. by repeated precision levelling.

The suggested thickening rates of a few centimetres per year for the interior ice-sheet regions, however, do not necessarily mean that the Greenland ice sheet as a whole is at present gaining mass. Observations from the ice-sheet margin in West Greenland indicate that in general this part of the ice sheet is thinning and receding (Bauer and others, 1968; Weidick, 1975; Seckel, 1977). Whether the gain in the central parts of the ice sheet, or the loss in the western marginal areas is the larger, cannot be determined on the basis of the data available.

Moreover, an even greater uncertainty concerning the mass balance of the total Greenland ice sheet arises from the fact that almost nothing is known about the mass balance of the eastern and northern parts of the ice sheet.

In connection with a search for possible explanations for the indicated surface-elevation increase in the central areas of the ice sheet, the effect of the slow thinning of the layer of sof $t$ Wisconsin ice, which at present constitutes the bottom $10 \%$ of the ice sheet at Dye 3 , and the contemporary thickening of the three to four times harder upper layer of Holocene ice (Gundestrup and Hansen, 1984; Dahl-Jensen, 1985), should be considered. This change will cause a thickening of the ice sheet, which can be calculated to be of the order of a few centimetres per year (paper in preparation by $\mathrm{N}$. Reeh). Therefore, this effect should be considered a contributing cause of the suggested small surface-elevation change, on equal terms with past changes of accumulation rate and long-term changes of basal ice temperatures in response to the glacial-interglacial climate cycle (Whillans, 1981).

\section{ACKNOWLEDGEMENT}

This work has been sponsored by the Danish Commission for Scientific Research in Greenland, the Danish Natural Science Research Council, and the
Commission of the European Communities under contract CLI-067-DK(G). Precise satellite ephemeris has been provided by the U.S. Defense Mapping Agency, Hydrographic/Topographic Center.

\section{REFERENCES}

Bauer, A., and others. 1968. Movement et variation d'altitude de la zone d'ablation oest (latitude moyenne $69^{\circ} 40^{\prime} \mathrm{N}$ ) de l'indlandsis du Groenland entre 1948 et 1959 , by A. Bauer, W. Ambach, and O. Schimpp. Meddelelser om Gronland, Vol. 174, Nr. 1.

Dahl-Jensen, D. 1985. Determination of the flow properties at Dye 3, south Greenland, by bore-holetilting measurements and perturbation modelling Journal of Glaciology, Vol. 31, No. 108, p. 92-98.

Gundestrup, N.S., and Hansen, B.L. 1984. Bore-hole survey at Dye 3, south Greenland. Journal of Glaciology, Vol. 30 , No. 106 , p. $282-88$

Mellor, M. 1968. The Greenland mass balance; flux divergence considerations. Union de Géodésie et Géophysique Internationale. Association Internationale d'Hydrologie Scientifique. Assemblée générale de Berne, 25 sept. - 7 oct. 1967. [Commission de Neiges et Glaces.] Rapports et discussions, p. 275-81. (Publication No. 79 de l'Association Internationale d'Hydrologie Scientifique.)

Mock, S.J. 1976. Geodetic positions of borehole sites of the Greenland Ice Sheet Program. CRREL Report (Hanover, NH) 76-41.

Overgaard, S., and Gundestrup, N.S. In press. Bedrock topography of the Greenland ice sheet in the Dye 3 area. American Geophysical Union. GISP Monograph.

Raymond, C.F. 1984. Deformation in the vicinity of ice divides. Journal of Glaciology, Vol. 29, No. 103, p. 357-73.

Reeh, N., and others. 1978. Secular trends of accumulation rates at three Greenland stations, by $\mathrm{N}$. Reeh, H.B. Clausen, W. Dansgaard, N. Gundestrup, C.U. Hammer, and S.J. Johnsen. Journal of Glaciology, Vol. 20 , No. 82 , p. $27-30$.

Reeh, N., and others. In press. Dating the Dye 3 deep ice core by flow model calculations, by N. Reeh, S.J. Johnsen, and D. Dahl-Jensen. American Geophysical Union. GISP Monograph.

Seckel, H. 1977. Höhenänderungen im grönländischen Inlandeis zwischen 1959 und 1968. Meddelelser om Gronland, Vol. 187, Nr. 4.

Shumskiy, P.A. 1965. Ob izmenenii massy lednikovogo pokrova $v$ tsentre Grenlandii [Variation in the mass of the ice cap in central Greenland]. Doklady Akademii Nauk SSSR, Tom 162, No. 2, p. 320-22.

Weidick, A. 1975. A review of Quaternary investigations in Greenland. The Ohio State University. Institute of Polar Studies. Report No. 55.

Whillans, I.M. 1981. Reaction of the accumulation zone portions of glaciers to climatic change. Journal of Geophysical Research, Vol. 86, No. C5, p. 4274-82.

Whillans, I.M., and others. 1984. Ice flow leading to the deep core hole at Dye 3, Greenland, by I.M. Whillans, K.C. Jezek, A.R. Drew, and N. Gundestrup. Annals of Glaciology, Vol. 5, p. 185-90. 